\title{
The Process of Self-Realization-From the Humanist Psychology Perspective
}

\author{
Marinela Rusu (10 \\ ICES “Gh. Zane”, Romanian Academy Branch of Iași, Iași, Romania \\ Email: marinela1808@yahoo.com
}

How to cite this paper: Rusu, M. (2019). The Process of Self-Realization-From the Humanist Psychology Perspective. Psychology, 10, 1095-1115.

https://doi.org/10.4236/psych.2019.108071

Received: May 21, 2019

Accepted: June 25, 2019

Published: June 28, 2019

Copyright () 2019 by author(s) and Scientific Research Publishing Inc. This work is licensed under the Creative Commons Attribution International License (CC BY 4.0).

http://creativecommons.org/licenses/by/4.0/

\begin{abstract}
Humanistic psychology has provided a series of fundamental theories about human personality and its development. Prominent representatives such as A. Maslow, C. Rogers or R. Assagiolli, along with the psychoanalyst C. G. Jung, have defined the basic concepts that help us today to better understand the individual evolutionary path from intuitive thinking structures and primary group integration, to elements of metacognition, creativity and integration into society through high moral values. Self-realization is a complex process that needs to be addressed from a number of perspectives, to provide a more complex and true picture of how individual development takes place. The paper aims to identify the role of family, interpersonal relationships, to understand which are the functions of knowledge and emotional experiences during development and actualization of individual's own potential. Achieving self-realization involves going through some stages, overcoming various difficulties and, above all, practicing self-regulation over individual emotions and behaviors. Education also provides the logical-scientific basis of going beyond the stages of self-realization, it provides insight and understanding, but it also means overcoming the theoretical boundaries, through personal involvement in actions that reflect moral and humanistic values. Positive and active approaches are ways that lead to self-realization.
\end{abstract}

\section{Keywords}

Self-Realization, Self-Actualization, Personality, Moral Values, Motivation

\section{Introduction}

Making an insight into the series of theories that discuss about personality fulfillment, we have taken into account the most important personality traits and have consistently referred to the moral values and social commitment of the in- 
dividual. As a psycho-social being, man succeeds in getting to know himself and others, to build an ideal of life only by interacting with others and only by reference to the social-moral values specific to the historical times in which he/she lives. Humanistic psychology has provided a series of fundamental theories about human personality and its development. Prominent representatives such as A. Maslow, C. Rogers or R. Assagiolli, along with the psychoanalyst C. G. Jung, have defined the basic concepts that help us today to better understand the individual evolutionary path from intuitive thinking structures and primary group integration, to elements of metacognition, creativity and integration into society through high moral values. Self-realization is a complex process that needs to be addressed from a number of perspectives, to provide a more complex and true picture of how individual development takes place.

The motivation of this research of a theoretical and conceptual nature is provided by the current need for personality development in accordance with its own tendencies and abilities. Today's society, due to its vast complexity, does not want an individual development that only pursues the requirements and standards of society, but wants the fulfillment or achievement of each individual's potential in the direction he/she can and wishes.

The methods used in this investigation include analysis, comparison and synthesis. Also, some analogies and generalizations are made in presenting and analyzing the theories and their fundamental concepts.

Thus, we will analyze Maslow, Rogers and Jung's humanist and psychoanalytic approaches, followed by the analysis of Assagioli's psychosynthesis theory, concluding this overview with the spiritualist theory of Ken Wilber, calling for a superior, transcendental dimension, in explaining the self-realization of the individual. Each of the described theories is accompanied by a critical, final approach.

\section{The Process of Individualization in Carl G. Jung's Theory}

1) Self-Realization. Although at the beginning of his career Jung (1875-1961) embraced the concepts of psychoanalysis and important ideas of Freud (1933, 1937), however, he later considered that some of them are not truthful and cannot explain the delicate mechanisms of psychic functioning. Thus, Jung did not agree with Freud that religion was a neurosis, a return to childhood fears that had to be left aside as a sign of the development of adult life. Jung considers religion to be psychologically necessary for mental well-being, especially in the second half of life, but also to achieve social cohesion. He rejected the Freudian thesis, which claims that neurosis is a consequence of sexual conflicts and repressed aggressive tendencies, and said: "A psychoneurosis must ultimately be understood as the suffering of a soul who has not discovered yet its meaning" (Jung, 2016: p. 199).

Jung is the one who introduced the term "self-realization," which was later taken over and analyzed by the humanistic psychological movement. This was 
one of the most important concepts in the systems of Abraham Maslow and Carl Rogers. Jung spoke about individuation as a tendency of the evolution of personality towards a coherent and integrated ensemble. The idea of accumulation and lifelong personality development was an unprecedented approach to psychological theories of the last century. Even a very old person, Jung said, could have surprising and useful insights if he were willing to look deep inside. This was a new, modern approach to personality.

2) Individuation. One of the essential elements in the Jungian theory, individuation, at the same time gives meaning, purpose and law, and can be considered another kind of "getting out of concealment" (Jung, 2011: p. 89), a disclosure of the self. This is because the individuation that C. G. Jung called the "central concept" of his psychology, although it is an unconscious process, refers to a widening of the sphere of consciousness and conscious psychic life. This means differentiating and becoming of the individual, otherwise than prescribe the collective norms; as Jung said, "to become an individual being, to the extent that, by individuality, we understand our most intimate, ultimate and incomparable uniqueness, means to become our own self” (Jaffe, 1996: p. 408). Jung believes that this process is not just about psychic life because it is manifested in all living organisms. Thus, he states explicitly: "Individuality is the expression of that biological process-simple or complicated, as is the case-by which every living thing becomes what was destined to be from the beginning" (Jung, 2011: p. 73). We have to do with a long and difficult process through which each "becomes himself". Thus, an unconscious and timeless integration of the self takes place in the conscious personality related to the present world we live in (Rusu, 2001, 2003a).

The stages of the individuation process go through both unconscious and conscious level, as it is evident from Jung's statement: if it "unfolds unconsciously, as it has always done, it does not mean no more than the transformation of an acorn into an oak... and of a child into an adult. But if the process of individualization is conscious, the conscious must be confronted with the unconscious for this purpose, and a balance must be found between opposites" (Jung, 1994: p. 306). It then continues to further deepen the differences between the two ways of realizing individualization: "The difference between the process of natural individuation, which unfolds unconsciously, and the consciousness one is huge. In the first case, consciousness does not intervene anywhere, therefore, the end remains as obscure as the beginning. In the second case, on the contrary, there is so much obscurity in the light that the consciousness gains inevitably, in breadth and understanding. The confrontation between the conscious and the unconscious must guard, as the light that shines in the darkness, and not only to perceive and understand the darkness, but to understand the darkness itself" (Jung, 1994: p. 292). By balancing contradictions as well as understanding shadows, Jung states, in fact, the need to complement the contradictions existing within us, which must be transformed into a coexistence of the opposites. 
3) Sacred Psychology. Introducing the idea of the soul and the importance of meaning as a critical factor in overcoming psychological stress, Jung recontextualized psychology as a sacred psychology and promoted a religious attitude, a relationship with God, and the cultivation of a spiritual life essential to a healthy personal development. We must note, however, that on many occasions Jung insisted that he does not speak of God as an absolute being, since it is not accessible to our knowledge but affirms the experience and the psychodynamic image of the divine, and recalls how it was expressed by people in different cultural symbols and images. Jung is not a theologian. He points out that human beings have this unique ability to formulate positive and/or negative images of an absolute creator. Jung (2016: p. 214) believes that the essence of psychic nature is a kind of disposition for this creator, while a religious attitude can be reflected either in devotion to a traditional god, or in patriotism, or in the fervor for a football team, or in pursuit of its success in any other form that ordinates people's lives and gives them meaning and purpose.

4) Archetypes. It is important to emphasize that the self is the integration and improvement of personality resulting from a continuous process of development that Jung calls individuation or the inherent unity of human being with its own nature (Brinich \& Shelley, 2002). Individuation as a developmental process involves the differentiation and integration of such personality components as: the ego (the organizer of the conscious mind), the shadow (the unconscious aspect of the individual), the persona (the social mask adopted in response to the requirements of the environment) and the animus/anima (the male and female contradictions of the person). By exercising the psychological functions of thinking, feeling and intuition, they gradually pass under the conscious control of the self, which constitutes the new, recent ego, so that the person attains self-realization, thus becoming an individual who feels the psychic fulfillment. Jung can be called a precursor of transpersonal psychology as he confers the primordial role of the spirit in human actions and brings the soul and the spirit to the counseling room, offering invaluable concepts and techniques for the psychological work. The need for individuation, this genuine "evolutionary process of personality," is viewed by Jung as introspection, which it regards as "self-focusing" and which, far from subduing it, regards it as an integrative, unifying process: "Introspection or the need for individualization-which is the same thing-gathers what is scattered and multiple, elevating them to the original form of the One, the primordial man. Through this separate existence, the Ego category is abolished, the circle of consciousness is widened and, through the awareness of paradoxes, the sources of conflict are exhausted" (Jung, 1994: pp. 167-168).

5) Stages of individuation. This essential, but long, permanent and endless process that is the individuation, that crosses our life from the beginning to the end, is completed in two major stages; the first ends in mid-life (30 - 40 years), and the second in old age. The first stage is defined by the adaptation of man to 
the external environment, accompanied by the establishment and maintenance of personal relationships in a broad social framework as well as by the development of an appropriate Persona. Personality is the external attitude, the outer character, "a functional complex consisting of means of adaptation, but which does not identify with individuality". "This functional complex refers exclusively to the relationship with objects" (Jung, 2016: p. 515).

6) Conscious and Unconscious. Once the Self is the central archetype, it means that the process of realizing the Self will have to be directed archetypally. The self, therefore, has a double role in this process: on the one hand, it is the initiator of the process, on the other, is the goal it is aiming for. It becomes both process and finality, the way and the truth that comes to its end. From this perspective, individuation can be seen as a process by which man discovers and attains divinity from himself, becomes the "image and likeness of God". This does not happen without much suffering, reflection, determination, but supposed efforts, when successful, are fully rewarded by the end result: reaching the joy of living by reaching unity/totality with the Self. If we were to look at the process of individuation through the metaphor of the journey, for example, where the journey itself is more exciting and thrilling, more satisfying and joyful than the point of arrival, then it means that the essence of individuation is "the journey" itself, the process of self-realization of the individual. Individuation is a continuous process of development, accumulation and resignation of meaning throughout life, a creative process: to the extent that we integrate and accept the unconscious part of us, we become more authentic, remodeling ourselves, and that brings us closer to perfection. The permanent confrontation between conscious and unconscious in the form of a continuous dialogue in which their contents are unified in symbols, leads to individuation. Practically, the symbol of the Self can be anything and anyone, from Christ to Buddha, from a circle to a square. Carl Jung stated: "The conscious and the unconscious do not make a whole if they repress and mutter each other. If they have to fight each other, then at least it should be a right fight and each side should have the same rights. Both are aspects of life. Conscience should defend reason and the possibility of self-protection, and the chaotic life of the unconscious should be able to follow its own path, as long as we can endure it. It means open struggle and open collaboration at the same time. This is how it seems people's life should look. It's the old hammer and the anvil game. The iron that suffers between the two is polished and becomes an indestructible whole, namely an 'individual'. That's about the individuation process. As the name indicates, it is a process or a development that comes from the conflict of the two basic soul realities." (Jung, 2012). Returning to oneself is a complex process that will be accomplished not only through introspection but also through education, by taking over and understanding spiritual and moral values in the history of mankind.

Synthesizing we can say that for Jung's psychoanalytic theory, self-realization is the result of confronting the contents of the conscious and unconscious level 
of the individual. This is the only way to move from child to adult stage. A characteristic feature of this approach is the introduction of the soul idea and the re-contextualization of psychology (sacred psychology). Self-realization, claims Jung is a developmental process that involves the differentiation and integration of such personality components as: ego, shadow, persona and animus/anima. Individuation is a continuous process of accumulation and resignation of meaning throughout life, a creative process. To the extent that we integrate and accept the unconscious as a part of us, we become more authentic, remodeling ourselves, being closer to perfection.

\section{Abraham Maslow-Motivation and Self-Actualization}

If Jung appealed to the levels of consciousness, showing the importance of its abisal dimensions in the process of thought and creation, Maslow, in particular, brings into discussion the role of awareness and the will to become a fully-actualized being.

1) Pyramid of Needs. Acquisitioning the term of self-actualization from Jung's theory, Abraham Maslow (1908-1970) integrates it into a complex theory of individual development. The known pyramid of needs, which presents the psycho-physiological causes of individual evolution, includes as a corollary, the stage of self-actualization, of personal perfection. By explaining a dialectic that exists between the unconscious/conscious levels, Maslow actually gets to say that the level of awareness of the ego represents the entry into the higher category of $B$ needs (meta needs). Once we reach this level, we can say that the self-actualization process really starts. But what are the meta needs and how do they help us in self-realization?

2) Meta-Needs. Starting from the premise that the motivation of healthy people with exceptional achievements is at least as interesting and valuable as that of people with mental disorders, Maslow has been concerned about understanding how these people become intrinsically motivated in their work, enrolling in an ascending spiral of self-improvement. Self-actualization is a growth motivation that is found within each individual, a need to develop his own psychic potential, of the body itself (Maslow, 1993: p. 289). His study included eminent people from different areas of his contemporary social life, who accepted to participate in the research, subject to confidentiality, historical figures with extensive biographical data, cases studied by other psychologists. The common factor of all these personalities is of a motivational nature: all those subjects were animated by needs that Maslow will call them meta needs (or B needs, Maslow: 1970, p. 19), which are a special form of motivation. "Individuals who become self-actualizing (becoming more mature, more plenary human) by definition have acceptably satisfied their basic needs and are now motivated in superior ways, which can be called meta-motivation" (Maslow, 1970: p. 20). Broadly speaking, Maslow differentiates two categories of motivational forces:

- D-needs (deficiency needs) - needs induced by a deficit-when unsatisfac- 
tion produces tension, and satisfaction produces tension reduction (they have a homeostatic role);

- $B$-needs (needs)-needs to become/grow-where satisfaction generates new tensions, thus propelling the being into an ascending process of self-improvement, a process that results in outstanding social or professional achievements.

This differentiation is maintained at the level of knowledge (B-cognition and D-cognition) and extends to the functioning of the whole personality (affectivity, activity). The psychology of personality, as he proposes, is a psychology of becoming (Being Psychology, Maslow, 1968). The failure of achieving the meta-needs produces a meta-pathology that is different from the disturbances which accompany the pathology associated with deprivation in the case of type $\mathrm{D}$ needs. Meta-needs are present in people whose lives have been marked by peak experiences, through which these individuals have achieved the integrity of the self, the sense of identity and personal completeness. From the set of meta-needs identified-B-values, some of a greater important are revealed: truth, kindness, beauty, transcendence, justice, wealth/multiplicity, perfection, uniqueness, vivacity, etc.

3) Growth or Stagnation. Self-actualization means courage, effort, risk-taking, and sometimes suffering. Many people are afraid to risk, because every action in the direction of change can be successful or failing. Man is ambivalent to his success or that of others: "...We certainly love and admire any person who embodies the values of truth, kindness, beauty, righteousness, perfection, and ultimately, success. And yet, these people make us feel embarrassed, anxious, confused, maybe a little jealous and envious, a little bit inferior and left-handed. They make us lose our aplomb, self-mastery and self-esteem" (Maslow, 1993: p. 72).

An interesting concept described in Maslow's humanistic theory is the Iona complex. Every individual is at a certain moment in life, in front of a choice between growth and stagnation. First-time employment is risky and people who have not acquired the motivation, courage and the ability to take risks during their training will choose the way of stagnation (they will never get out of the belly of the whale). If we plan goals that are below our potential, we risk being unhappy and tense for the rest of our lives just because we have escaped from the trajectory of personal fulfillment (Maslow, 1970: p. 32).

4) Multiple Motivations of Behavior. These needs should be understood not to be exclusive or unique to certain types of behavior. An example can be found in any behavior that appears to be physiologically motivated, such as food, sexual play, or the like. Clinical psychologists have long found that any behavior can be a means by which different determinants are manifested. Most of our behavior has a multiple motivation. The need to eat may be partly due to filling the stomach and partly for reasons of comfort and improvement of other needs. It is possible to make love not only for pure sexual release, but also to convince 
someone of our masculinity/femininity, or to make a conquest, to feel strong or to gain more affection or safety. Analyzing a single act of an individual we can see in it the expression of his physiological needs, safety, love, self-actualization needs. This contrasts with the more naive idea of psychology of traits, where a feature or reason represents a certain type of act (for example, an aggressive act is the result of an aggression trait).

5) The Need for Love. If both physiological and safety needs are well-satisfied, then the needs of love, affection and belonging and the whole cycle already described will be repeated having this new center (Maslow, 1993: p. 381). Now, the person will feel-stronger than ever-the absence of friends or a lover, a wife or the absence of children. He/she will neglect strict physiological needs in favor of affective relations with people in general, that is, for a place in his group, and will strive with great intensity to achieve this goal. He/she will want to get such a place more than anything else in the world. In our society, alleviating these needs is the most common nucleus in more severe maladaptation and psychopathology. Love and affection, as well as their possible expression in sexuality, are generally viewed with ambivalence and are usually accompanied by many restrictions and inhibitions. In essence, all theoreticians of psychopathology have emphasized that the improvement of the need for love is essential in the image of individual inadequacy. Therefore, many clinical trials have been done on this need and we know more about it than any of the other needs (Maslow, 1968: p. 112). In this analysis, love is not synonymous with sex. Sex can be studied as a purely physiological necessity. Regular sexual behavior is multidimensional, that is, determined not only by sexual needs, but also by other needs, including the needs of love and affection. It should not be neglected that the need for love implies both giving and receiving love.

6) The Need to Be Respected. All the people in our society (with some pathological exceptions) have the need or the desire for a stable, solid (usually) self-required assessment to gain self-esteem and respect from others. Through self-esteem, we understand the capacity and real respect for others. These needs can be classified into two subsidiary sets: the desire for power, achievement, suitability, trust in the world, independence and freedom. Secondly, we have what we may call the desire for reputation or prestige (defining it as respect or appreciation by other people), recognition, attention, importance or appreciation (Maslow, 1970: p. 33). These needs were relatively underlined by Alfred Adler (1938) and his followers and were relatively neglected by Freud and psychoanalysts. More and more today, they are considered to be of central importance. "Satisfaction of self-esteem need leads to feelings of self-confidence, worth, strength, ability and adequacy of being useful and necessary in the world. But the thwarting of these needs produces feelings of inferiority, of weakness and of helplessness. These feelings in turn give rise to either basic discouragement or else compensatory or neurotic trends. An appreciation of the necessity of basic self-confidence and the understanding of how helpless people are without it, can 
be easily gained from a study of severe traumatic neurosis” (1970: p. 21).

7) The Need for Self-Actualization. Even if all these needs are met, we can still often (if not always) expect new discontent and anxiety to develop soon, if the individual does not do what is right. A musician has to make music, an artist has to paint, a poet must write, if he wants to be, finally, happy. What a man can be, it must be. This need can be called self-actualization. This term, originally conceived by Kurt Goldstein (quoted by Washburn, 1994: p. 54), is used in a much more specific and limited way. It refers to the desire for self-fulfillment, namely the tendency to become everything that someone is capable of becoming. The specific form of these needs will be very different from person to person. In one case, it may take the form of the desire to be an ideal mother, for another person it can be expressed in athletic performances, and for another may be expressed in making photos or inventions. The clear emergence of these needs, Maslow believes, is based on the prior satisfaction of physiological, safety, love and esteem needs. Such an affirmation is a partial solution to the general problems of curiosity, the search for knowledge, truth and wisdom, and the ever more persistent need to solve the cosmic mysteries.

8) Relative Satisfaction. What we have previously presented may create the impression that basic needs respect a certain logical, "wise" order in their fulfillment. We have stated that "if a need is satisfied, then another appears" (Maslow, 1970: p. 24). The false impression is that a necessity must be satisfied $100 \%$ before the next need arises. In fact, most members of our society who are normal are partially satisfied in all their basic needs and partly unsatisfied in all basic needs at the same time. A more realistic description of the hierarchy would be in terms of lowering satisfaction rates as we ascend higher in the hierarchy. We could exemplify through an average model of satisfaction: probably $85 \%$ of its physiological needs, $70 \%$ in its safety needs, $50 \%$ in its love needs, $40 \%$ in its self-esteem needs and 10\% in its needs of self-actualization (Maslow, 1970: p. 30).

The normal person is animated by meta-needs-B-values-and is characterized by functioning at the highest level of his/her potential. This kind of functioning is the sign of mental health. The psychological pathology is given by limiting and distorting the satisfaction of these needs of becoming (B-values). If we define the normal person as being adapted, in terms of the plenary development of his capacities, we do so by reference to an ideal man who, in fact, is the natural and healthy man. Ultimately, the normal person is the mature personality, who is self-actualized.

In conclusion, we can say that Maslow's theory brings into the center of self-realization process (which he calls self-actualization) the concept of the awakening consciousness, the awareness of the ego that makes the transition to the needs of being (Beta needs) - which include the moral values: truth, kindness, beauty, transcendence, justice, wealth/multiplicity, perfection, uniqueness, vivacity, etc. Starting from these ideas, current psychology is increasingly focus- 
ing on career success (Dai \& Song, 2016), as an analogous motivation to self-realization. Also, Jim Meade (2000) suggested that career success is the result of personal experience and could be seen as personal experience and the accumulation of real or perceived accomplishments, so that career success involves subjective career successes and objective career successes (Hosseinkhanzadeh \& Taher, 2013).

At the same time "parent's education, home stability, economic issues, cultural interests, home relationships, and cultural community opportunities are factors that determine the quantity and quality of the information received by the child, producing learning" (Lanz, Fernández, Fernández, \& Valdez, 2017: p. 281). It is important to understand the relationship between parental education and children academic performance, as the results show that parents with professional degree and postgraduate have children with good academic performance, compared with the parents with lower grade studies (Lanz et al., 2017: p. 283).

Self-actualization to be fulfilled implies courage, effort, risk-taking, and sometimes suffering, frustration and isolation. Self-actualization is a growth motivation that is found within each individual, a need to develop his own psychic potential. The needs to grow-bring a satisfaction that generates new tensions, thus propelling the being into an ascending process of self-improvement, a process that results in outstanding social or professional achievements.

Two other key-concepts of this theory are: the multiple motivation of most of our behavior and the relative satisfaction of our important needs.

\section{Carl Rogers Humanistic Psychology}

While Maslow emphasizes the idea of effort in self-actualization, Rogers quotes this process as a natural tendency in nature, which only acquires a specific characteristic in the case of man.

1) Actualization, states C. Rogers (1902-1987), is a biological phenomenon, but it becomes an active tendency towards self-actualization in human beings. The general tendency towards self-actualization is the inherent contribution of the body in the development of all its capacities for maintaining or improving it. This constructive biological tendency, the only postulated by C. Rogers (2008, 2012), is the central source of energy in the human body. The actualization tendency is expressed in a wide range of behaviors in response to a wide variety of needs. It has four significant features:

- is an organic, natural, innate predisposition.

- is an active process of initiating, exploring, producing change in the environment, playing and even creating (to meet human needs).

- it is direct and guides every form of life towards growth, self-regulation, fulfillment, reproduction, and independence from external control.

- it is selective-which means that not all the potentials of an organism develop with necessity. 
2) Self-Actualization. Rogers has postulated that the human tendency is naturally directed towards self-actualization. The tendency toward self-actualization is the whole process through which the individual achieves his potential, to become a fully functioning person. What is actualized is the expression of the self-fulfillment of the human body-specific tendency to be what only what it can be. The tendency of self-actualization is always towards a "better life". Rogers has associated the process of self-actualization with the stimulation of functioning in three areas:

- first of all, self-realization requires an increased openness to a diversity of experiences.

- secondly, self-actualized people participate in every moment in their lives, live in full. All life experience is now without preconceptions.

- third, people give confidence to their own body, to what they feel and perceive. They trust the freedom of decision, creativity, etc.

3) The Importance of Self (Ego). The concept of self-actualization suggests the central role of the ego in Rogers's theory. The existence of the self seems to be clearly implicated in our daily language: $I$ am in love; these books are mine etc. In short, the importance of self is one that distinguishes humanist psychology from other currents. Rogers distinguishes the actual self from the ideal self. The present ego includes our perceptions of how we are now. The ideal self is everything we imagine, we hope and wish to be.

4) Personality. Rogers' work with clients, within his therapy, led him to identify the three necessary and sufficient conditions for the growth and change of personality:

- positive, unconditional approach: which assumes acceptance of being the person you are.

- accuracy of empathy: Rogers considered that the ability to understand another person is an essential value. The ability to correctly perceive a person's own world in a non-evaluative way has been named accurate empathy.

- congruence in interpersonal relationships. In the direction of knowing a person, others need to demonstrate their ability to be themselves in relation to this natural and open person.

5) Client-Centered Therapy. The theory of C. Rogers gives the person a full attention. Every individual is seen as having innate inclinations for self-actualization, under conditions of a favorable environment. If certain conditions exist, then a characteristic process of personality change will occur. These conditions include the three necessary and sufficient conditions mentioned above. In addition to them is added the client's anxiety. This therapy includes the client's motivation for change. Current research demonstrated scientifically that there is a link between intelligence and positive, open, unprejudiced attitude to the life (Furnham, 2017).

Summarily, C. Rogers builds his theory focusing on actualization as a biological, natural tendency of nature, which, however, becomes a conscious tendency 
in the case of self-actualization of human beings. It is an organic, natural, innate predisposition. This process can be characterized by the following specific features: it is an active process of initiating, exploring and it is selective-which means that not all the potentials of an organism will be developed with necessity. The purpose of this innate tendency is to become a fully functioning person. Also, self-realization requires an increased openness to a diversity of experiences, the capacity to live in full their lives, to give confidence to their own body, to trust the freedom of decision, creativity, etc. Regarding the personality development, Rogers describes a fundamental concept: the positive, unconditional approach.

\section{Roberto Assagioli and the Concept of Psychosynthesis}

The optimistic approach of Rogers's theory and client-centered therapy is continued by Assagioli, who adds the spiritual dimension to interpreting the individual's psychic life.

Roberto Assagioli (1888-1974) developed psychosynthesis, which, while has much in common with Jungian psychology, but differs in many important points. Assagioli's statement is that the development of the individual is not just an end in itself but a means to finish it. He believes that there is a natural progression to synthesis-a principle of sophisticated interdependence, which means the creation of higher level of organization both within the individual, between and beyond individuals. Synthesis is a dynamic towards integrity that reconciles the daily experience of multiplicity with a familial desire for unity. It is an intrapsychic, interpersonal and transpersonal organizational principle: "...the spirit that works on and within the whole creation ...shaping in order, harmony and beauty, uniting all beings ...with each other through love ties, slowly realizing and in silence, yet powerful and irresistible - the Supreme Synthesis" (Assagioli \& Firman, 1965/2010: p. 31). Assagioli notes: “...the spiritual is as basic as the material part in man" (Assagioli, 1965: p. 193). Psychosynthesis definitely affirms the reality of spiritual experience, the existence of higher values and of the noetic or noological dimension (Assagioli, 1965: p. 195). The aim of psychosynthesis is: "...to include within the study of psychological facts all those which may be related to the higher urges within man which tends to make him grow towards greater realizations of his spiritual essence" (Assagioli \& Firman, 1965/2010: p. 193).

The spiritual word in its wider connotation therefore includes not only the specific religious experience, but all the states of awareness, all the functions and activities that have as a common denominator the possession of higher than average values, such as aesthetic ethics, heroic, humanitarian and altruistic values (Assagioli \& Firman, 1965/2010: p. 38). "Self-awareness rests at the core of a person's sense of self; thus, the human capacity to direct attention toward the self has fundamental personal, social, and cultural consequences" (Goukens et al., 2009: p. 685). According to original self-awareness theory, self-focused atten- 
tion makes people more conscious of their attitudes and beliefs (Gu \& Su, 2016: p. 228).

The principle of synthesis is identified in the process of developing consciousness and increasing will in forming individual personality (Rusu, 2003b). Psychosynthesis affirms that the essential human identity is that of a spiritual self and that this self exists as an ontological reality. It is the pure being and the stable center of life. Assagioli's assertion about the ontological reality of the self is quite different from that of Jung-as an archetype or primordial idea that seems to emphasize a more conceptual and abstract principle of psychic regulation.

Assagioli asserts that at the level of self-realization our experience with ourselves is a pure act of consciousness. We do not identify with our past or any mental construction or try to be others than those who we are spontaneously and truly at a particular moment. There is no effort to be alone and there is no need to do anything to be ourselves. We simply are. The individual can and often has the direct experience of self in altered states of consciousness such as joy, ecstasy, play and intuition, and there is, of course, a psychological journey that must be made to turn to who we are in essence and to those who we have always been. Certain features of that psychological journey are well described in psychoanalytic psychology, but gain a rather different emphasis in the theory of psychosynthesis development. Assagioli's assertions about development have been extended by Joan Evans $(1995,2003)$ and Jarlath Benson (2001) at the Institute of Psychosynthesis in London and are briefly summarized as follows:

1) In the First Stage of Development, the ego is the initial expression of self in the concrete world and the formation of the successful ego is the primary task of childhood. The ego is a vehicle or a psychological environment for the self and allows it to appear physically in the world. The ego has a consciousness and is a structure built from life experiences, fed by desires and instincts, supplemented with defense mechanisms, reacting to the environment and ensuring survival; but the ego is not yet aware of its own existence. Due to the normal and pathological processes of identification with the physical, emotional and mental aspects of his experience, the ego can mistakenly deceive us to become the source of our being; he does not understand that it is just the means by which we have to express who we are in essence. The psychosocial journey of the person through the life cycle is the usual method of correcting this erroneous identity.

2) The Second Stage of the Synthesis is the self-awakening in the concrete world or the appearance of the "ego" consciousness and purpose. Usually, in adolescence and afterwards, personal self or the feeling of "I" begins to appear. This experience of "I-ness" offers a sense of identity and continuity, even if our everyday experience and the world is constantly changing and developing. Will and intentionality are a function of the emergence of the " $\mathrm{I}$ " identity, and the evocation and activation of the will is a vital factor in its development. Since will is the direct expression and ability of individuals to function freely according to 
their own intrinsic nature and not to the constraint of external forces, the conscious act of will is one of the most powerful ways to experience the self as an autodynamic being, a free and responsible agent which initiates and regulates the action. That is why so much psychosynthetic therapy is aimed at evoking the aspects, qualities and stages of the expression of will.

3) The Third Stage of Development is mentioned in psychosynthesis as the stage of self-realization-the gradual consciousness that each one is essentially a self. This is usually a task of maturity and results from the experience and belief that the highest values of the individual extend beyond their personal character: they are aligned in action, service and compassion with the social and global spirit of the times and that the person, through his own psychological journey is indistinguishably identified with the greater journey of mankind. Thus, there is a psycho-spiritual context that not only serves to restructure and reorient personality but also to stabilization of belief that the purpose and objectives that appear are indeed resonant with the Spirit (Evans, 1995, 2003; Benson, 2001).

In conclusion, there is a natural progression to synthesis striving to reach a higher level of organization both within the individual, between and beyond individuals. Synthesis is a dynamic towards integrity and involves values higher than average, such as aesthetic ethics, heroic, humanitarian and altruistic values. The principle of synthesis is identified in the process of developing consciousness and increasing will in modelling individual personality. Psychosynthesis affirms that the essential human identity is that of a spiritual self. The three stages of self-realization in Assagioli's theory are: 1) Detachment from the identification with the physical, emotional and mental aspects of the personal experience (the ego); 2) Will and intentionality become a function of the emergence of the "I" identity-the evocation and activation of the will (specific of adolescence and afterwards); 3) The third stage is usually a task of maturity and it includes the reference to the destiny of all humanity, in a spiritual vision.

It can be said that psychosynthesis involves knowing and deepening the personality, realizing the true self, and finally, re-forming or reconstructing the personality around this new center.

\section{Levels of Consciousness. Ken Wilber and Evolution towards Transcendence}

Assagioli offered openness to the spiritual interpretation of the self but Wilber was the one who presented in a particularly complex picture of the stages and their content in the individual evolution towards self-fulfillment and realization.

1) Spectrum of Consciousness. Kenneth Earl Wilber II (born January 31, 1949) is an American writer on transpersonal psychology and his own integral theory (Rentschler, 2006) is a systematic philosophy which suggests the synthesis of all human knowledge and experience. Ken Wilber is probably the most important transpersonal theoretician who has developed a model of growth and human development that integrates Western psychology and philosophy with 
Eastern concepts of personality and consciousness. His model of spectrum of consciousness describes a series of stages in development in which successive tasks must be performed successively before the person can move to the next stage (Wilber, 2001, 2002). This linear model is based on a gradual ascension, from primitive, inferior states of consciousness to superior mystical experiences, and ultimately, to a peak that is made by very few but theoretically it is accessible to anyone.

2) Seven Stages and Three Areas. Wilber has distilled the 7 basic levels or structures that constitute the fields of matter, body, mind, soul, and spirit in seven stages and three domains (Wilber, 1998).

- The first stage, which is called the "archaic" stage-includes the material body, sensations, perceptions and emotions. This is roughly equivalent to Jean Piaget's (1976), Piaget \& Inhelder (1963) description of sensory-motor intelligence and Abraham Maslow's image of physiological needs. If the self develops poorly at this stage, the individual may suffer psychotic disorders in later life, but if the self develops normally, it progresses smoothly in the next stage.

- In the second phase, Wiber calls for a "magical" vision of the world, because the oldest mental productions and rudimentary concepts represent a shift towards the "omnipotence of thought". This stage is similar to Freud's concept of primary process, Piaget's preoperative thinking, and is correlated with Lawrence Kohlberg's preconventional morality and Maslow's safety needs. Disturbance at this stage will lead to narcissistic and limit pathologies.

- The third stage is called "mythical" and although it is more advanced than the magical state, the self is not yet capable of clear rationality, hypothesis, or rational thinking.

- The fourth stage of development is called "rational" because the evolving self can not only think but also think; is thus introspective and capable of hypothetical reasoning and testing as well. This stage is equivalent to Piaget's formal operational thinking, Kohlberg's post-conventional morality (Kohlberg, 1981) and Maslow's self-esteem needs.

- The fifth stage of human growth is called by Wilber "psyche", which does not refer to paranormal, but refers more to the beginning of transpersonal, spiritual or contemplative development, imagination, vision, and soul life. Maslow would describe this stage as being concerned about self-actualization needs.

- The sixth stage is the "subtle" or intermediate stage of spiritual development and is concerned with intuition and enlightenment. It correlates with Jung's archetypal level and with Maslow's need for self-transcendence.

- The seventh stage is called "causal" in the sense that it is the limit of growth and development and is the "the theme of being", well described by Tillich (1952).

Wilber has consolidated his evolutionary consciousness model in three very 
useful ways of differentiating reality-prepersonal, personal and transpersonal. As we have seen, each of these levels has its own achievements and failures in development, and various schools of psychotherapy and philosophical systems have evolved to meet the specific requirements of reality. This perspective eliminates competition between schools and thinking systems and demonstrates convincingly that the different schools have special expertise and competence in each of these areas.

3) Pre/Trans Fallacy. Wilber also contributed with an interesting analysis of the common confusions between prepersonal and transpersonal experiences that he calls the pre/trans fallacy (2001). This differentiation is very useful for the clinician who wishes to determine whether a particular individual suffers from psychotic illusions or has truly reached a spiritual knowledge. This error or misconception of phenomena has two major forms. In the first form, transpersonal experiences are reduced to the functioning of the predominant psychological dynamics. Wilber appreciates Freud for all his indisputable merits, but considers an incorrect and inconsistent approach to true religious and spiritual experience in expressions such as id, sex, emotion and nature, thereby removing the possibility of transcendence of ego and of a higher-level integrity.

Synthesizing we can say that Wilber created a consistent model of growth and human development that integrates Western psychology and philosophy with Eastern concepts of personality and consciousness. His model of spectrum of consciousness describes a series of stages in which successive tasks must be performed before the person can move to the next stage. This linear model is based on a gradual ascension, from primitive, inferior states of consciousness to superior mystical experiences, and ultimately, to a peak that is reached by very few but theoretically it is accessible to anyone.

The seven stages in spiritual evolution, as presented by Wilber, are: 1) The "archaic" stage; 2) The "magical" vision of the world; 3) The "mythical"-the self is not yet capable of clear rationality, hypothesis, or rational thinking; 4) The "rational" stage; 5) The "psyche" stage, which refers to the beginning of transpersonal, spiritual or contemplative development, imagination, vision, and soul life; 6) The "subtle" or intermediate stage of spiritual development-intuition and enlightenment; 7) The "causal" in the sense that it is the limit of growth and development. A key-concept created by Wilber is the one who talks about the common confusion between prepersonal and transpersonal experiences named the pre/trans fallacy.

There is no doubt that Wilber is a first-rate theoretician and constructor of models, and his ability to differentiate and integrate concepts has contributed in particular to the development of transpersonal and psycho-spiritual psychology and its growing acceptance as a new paradigm in psychology. However, John Heron (1998) emphasized, inter alia, that Wilber's model of the transpersonal and psycho-spiritual domain does not have a dynamic polarity, by pointing out rather the "ascension" than the "descent" and is a linear and hierarchical sim- 
plistic model.

\section{Comparative Analysis}

The theories presented are certainly a source of inspiration for contemporary psychology and therapy. The need for achievement is to accomplish something difficult, to master, manipulate or organize physical objects, human beings, or ideas (Sharma, 2013; Appel \& Kim-Appel, 2010) that are explained in these theories. However, a number of incompletely described elements, concepts without identifiable content through empirical data, or inconsistencies between theoretical descriptions and the very life of the individual can not be neglected.

Thus, if we mention some of the weak points of Jung's theory, we should recall its mystical and metaphysical tendency in interpretation, the lack of research accompanied by experimental measurements (Zappia, 2018). His concepts were created through a combination of the theoretical study and his practical experience as a psychiatrist, often avoiding direct confrontation with the confirmation or refutation of his theoretical predictions. Adam Frank (2009) is of the opinion that the archetypes described by Jung are not only elusive and incomplete, but lead to the preservation of cultural prejudices and myths contrary to the development of today's society. M. R. Gundry (2006) notes that we are confronted in Jung's theory with a subjective point of view, preferring the inner, subjective, empirical, experimental experience. As a result, we find here a specific form of reductionism, namely the tendency to reduce everything to a subjective, inner interpretation, doubled by a quasi-mystical, spiritualist perspective.

In the case of Maslow's theory of motivation, criticism points to the inconsistency between the sequence (hierarchy) of the needs and the real life of the individual (Kaur, 2013). At the top of the pyramid of needs, self-realization seems a purpose accessible to individuals, theoretically, but in reality, few are those who really achieve this level of professional or individual fulfillment.

The criticism of the theory of psychosynthesis and of the analogous therapy refers in particular to the lack of direct engagement with the concerns of the modern world, politically, socially and ethically (Parfitt, 2015). In the consulting room, the client feels helped, supported and guided, but once the session is over, he remains alone in the face of conflicts and stressful situations. The therapy promoted by the theory of psychosynthesis does not have the power to penetrate the life of the client.

Thorne and Sanders (2012) have made a critical approach to Rogers's theory, showing that he does not have enough empirical data taken over by research and experimentation. The holistic approach is interesting and generous, but it prevents the definition of concrete variables that could be investigated with accuracy. Likewise, as with Jung's theory, the tendency of subjective interpretation of psychic life is exaggerated, to the detriment of understanding the other dimensions of personality, such as the impact of society on personality deve- 
lopment.

Michael Washburn (1994) compared the models of Wilber and Jung (Assagioli's), concluding that these are two different paradigms that guide transpersonal theory and reflect different cultural perspectives. Washburn asserts that the Jungian (Asagiolian) paradigm conceive the human development as a result of a spiral course, a departure, and a higher return to the origins of being. From this perspective, ego initially starts from the deeper sources of the psyche, and then separates itself from these sources in the first half of life-the ego development and domination tendency period. In the second part of life, the ego returns to the deep regions of the psyche to be integrated, based on a more developed trans-ego level.

Wilber's model is, according to Washburn (1994), rooted in traditional cognitive-developmental psychology, and approaches human development as a straight line of ascension, from pre-egoic levels to egoic levels, and to trans-egoic levels. Washburn calls this model a paradigm of scale because it determines the path of development as a step-by-step climb in a hierarchy of psychic structures, including: knowledge, moral consciousness, and the structures of the self. Washburn suggests that the spiral paradigm owes much to Jung's theory of Western spirituality and esoterism, while the scale paradigm reflects Wilber's deep interest in Eastern spirituality, especially Buddhism and Vedanta, which emphasizes the linear progression of consciousness. The identification of the contrasting paradigms of sacred psychology by Washburn is a useful guide and allows the counselor/psychotherapist to properly find different models of human development and to select valuable elements about the client's particular trajectory.

Personality development theories have been criticized for neglecting or ignoring the significance of the historical, social, cultural and political context which led to their emergence and formation (Brinich \& Shelley, 2002). Intra-personal emphasis is so strong that many authors seem often aware of how much they are influenced by class, age, race, and gender attitudes in their own experience. Erikson (1968) attempted to address this perspective by placing his subjects in relation to society, but because his model is psychodinamic, he was still influenced by Freud's patriarchal attitudes and focused on autonomy and separation as top points of success. Levinson (apud Washburn, 1994), despite his apology, based his ten-year research project on men alone. It is therefore not surprising that theories (as many aspects of therapy) may be of no relevance to minority groups such as migrant workers in Europe or the US who struggle with daily demands to earn their bread in a unequal society.

Despite all the deficiencies of interpretation or approach to personality development, the great psychological trends have brought more insight into the levels/stages of development and the fundamental mechanisms which underlie this development. The critics of the old theories have only enriched and deepened the new approaches, continuing to understand the meaning of existence and self-realization. 


\section{Conclusion}

The current research aimed at highlighting the distinctive elements of the process of self-realization from different perspectives. We find a complex approach to personality, starting from the level of the unconscious and overcoming it through awareness and self-knowledge (Jung, Assagioli). Self-actualization, an intimate concept linked to self-realization, opens the way of non-conformism and freethinking, of achieving personal fulfillment and professional performance (Rogers).

The stage of self-awareness, overcoming the ego, justifies our access to aesthetic, moral values, to meta-needs and meta-values, towards the Truth, Good, and Beautiful of the ancient Greek philosophy. A special complexity requires self-realization at the spiritual level, sustains Wilber. It requires an entire psychic alchemy, a true instinctual, emotional "purification" to get to contemplation and enlightenment.

The contribution of this work is to emphasize the need to give importance to all levels of consciousness, to be able to be constantly overcome, and to gain self-realization and self-actualization. Contemporary education should integrate into its structures the reference to the ideal of life, to individual development consistent with its own tendencies and abilities. The theories presented represent the pillars on which contemporary psychology is built and their fundamental concepts have remained valid today in the approach and understanding of the human personality. Starting from this data, a comparative/evolutionary analysis of the current psychology guidelines can be made in the future in relation to the basic theories that generated it.

\section{Conflicts of Interest}

The author declares no conflicts of interest regarding the publication of this paper.

\section{References}

Adler, A. (1938). Social Interest. London: Faber \& Faber.

Appel, J., \& Kim-Appel, D. (2010). The Multipath Approach to Personality: Towards a Unified Model of Self. Psychology, 1, 273-281. http://www.SciRP.org/journal/psych https://doi.org/10.4236/psych.2010.14036

Assagioli, R. (1965). Psychosynthesis: A Manual of Principles and Techniques (p. 38, 95, 193). London: Aquarian/Thorsons.

Assagioli, R., \& Firman, D. T. (1965/2010). The Act of Will (p. 31). SYNTHESIS, CTR Incorporated.

Benson, J. F. (2001). Chap. 12. Working More Synthetically with the Group. In Working More Creatively with Groups. London and New York: Routledge. https://doi.org/10.4324/9780203137291

Brinich, P., \& Shelley, C. (2002). The Self and Personality Structure. London: Open University Press.

Dai, L. T., \& Song, F. H. (2016). Subjective Career Success: A Literature Review and 
Prospect. Journal of Human Resource and Sustainability Studies, 4, 238-242. https://doi.org/10.4236/jhrss.2016.43026

Erikson, E. H. (1968). Identity, Youth and Crisis. New York: Norton.

Evans, J. (1995). Psycho-Spiritual Psychology in Self and Society.

Evans, J. (2003). The Triphasic Model. In Psychosynthesis Therapeutic Counselling (Vol. 4). Kansas: Anamcara Press LLC.

Frank, A. (2009). The Constant Fire: Beyond the Science vs. Religion Debate. Reed Business Information, a division of Reed Elsevier Inc.

Freud, S. (1933). New Introductory Lectures on Psychoanalysis. New York: Norton.

Freud, S. (1937). The Ego and the Mechanisms of Defense. London: Hogarth.

Furnham, A. (2017). Personality and Intelligence in a High Ability Sample. Psychology, 8, 1355-1362. https://doi.org/10.4236/psych.2017.89088

Goukens, C., Dewitte, S., \& Warlop, L. (2009) Me, Myself, and My Choices: The Influence of Private Self-Awareness on Choice. Journal of Marketing Research, 46, 682-692. https://doi.org/10.1509/jmkr.46.5.682

Gu, Q. N., \& Su, Y. (2016). How Does Objective Career Success Affect Subjective Career Success? The Moderating Role of Self-Awareness. Journal of Human Resource and Sustainability Studies, 4, 227-237. https://doi.org/10.4236/jhrss.2016.43025

Gundry, M. R. (2006). Beyond Psyche: Symbol and Transcendence in C.G. Jung. AUS (American University Studies).

Heron, J. (1998). The Sacred Science: Person-Centred Enquiry into the Spiritual and the Subtle. Ross-on-Wye: PCCS.

Hosseinkhanzadeh, A. A., \& Taher, M. (2013). The Relationship between Personality Traits with Life Satisfaction. Sociology Mind, 3, 99-105.

http://www.scirp.org/journal/sm https://doi.org/10.4236/sm.2013.31015

Jaffe, A. (1996). Amintiri vise, reflecții, Consemnate de Aniela Jaffe (p. 408). Humanitas, București.

Jung, C. G. (1994). Puterea sufletului, Antologie în patru volume (pp. 167-312). Ed Anima.

Jung, C. G. (2011). Cartea Roșie. Liber Novus, Ed. Sonu Shamdasani, Editura TREI, București, p. 73, 89.

Jung, C. J. (2012). The Archetypes and the Collective Unconscious. Collected Works of C. G. Jung, Vol. I.9., Princeton: Bollingen Series, 288.

https://archive.org/details/collectedworksof91cgju

Jung, C. G. (2016). Psihologie şi alchimie-Opere Complete (Vol. 12, pp. 199-214). Editura TREI.

Kaur, A. (2013). Maslow's Need Hierarchy Theory: Applications and Criticisms. Global Journal of Management and Business Studies, 3, 1061-1064.

https://www.ripublication.com/gjmbs_spl/gjmbsv3n10_03.pdf

Kohlberg, L. (1981). The Philosophy of Moral Development. San Francisco, CA: Harper and Row.

Lanz, P. M., Fernández, A. C. L., Fernández, F. P., \& Valdez, M. P. H. (2017). Relevance of Family in Academic Success on Children. Health, 9, 279-288.

https://doi.org/10.4236/health.2017.92019

Maslow, A. H. (1968). Toward a Psychology of Being (pp. 46-47, 112). New York: Van Nostrand Reinhold. 
Maslow, A. H. (1970). Motivation and Personality (pp.19-33). New York: Harper \& Row.

Maslow, A. H. (1993). The Farther Reaches of Human Nature (p. 289, 381). New York: Penguin/Arkana.

Meade, J. (2000). Boost Careers and Succession Planning. HR Magazine, October, 175-178.

Parfitt, W. (2015). What's Wrong with Psychosynthesis? Psychosynthesis: Beyond Right and Wrong. 20 October 2015.

https://psychosynthesistrust.org.uk/will-parfitt-whats-wrong-with-psychosynthesis/

Piaget, J. (1976). The Child and Reality. Problems of Genetic Psychology. London: Penguin Books.

Piaget, J., \& Inhelder, B. (1963). The Child's Conception of Space. Paris: Humanities.

Rentschler, M. (2006). AQAL Glossary. Journal of Integral Theory and Practice, 1, 2-40.

Rogers, C. (2008). A deveni o persoană-Perspectiva unui psihoterapeut. București: TREI.

Rogers, C. (2012). Client-Centered Therapy: Its Current Practice, Implications and Theory. London: Little, Brown Book Group.

Rusu, M. (2001). Interior și exterior, subiectiv și obiectiv în psihologia transpersonală, în Studii și cercetări din domeniul științelor socio-umane, Ed. Limes \& Argonaut, ClujNapoca, Vol. 8, pp. 95-100.

Rusu, M. (2003a). Dimensiuni abisale ale individuării în psihologia lui C. G. Jung, în rev. Symposion, Tomul I, nr.1, Ed. Academiei Române, București, pp. 131-137.

Rusu, M. (2003b). Teoria psihosintezei și procesul actualizării de sine, în Studii și cercetări din domeniul științelor socio-umane, Argonaut, Cluj-Napoca, Vol. 11, pp. $56-62$.

Sharma, E. (2013). Personality Mapping: Tool to Analyze Achievement Orientation. iBusiness, 5, 59-64. https://doi.org/10.4236/ib.2013.52007

Thorne, B., \& Sanders, P. (2012). Carl Rogers (3rd ed., pp. 119-120). Thousand Oaks, CA: SAGE Publications. https://doi.org/10.4135/9781446289051

Tillich, P. (1952). The Courage to Be. New Haven, CT: Yale University Press.

Washburn, M. (1994). Transpersonal Psychology in Psychoanalytic Perspective (pp. 12-13). New York: State University of New York Press.

Wilber, K. (1998). The Spectrum of Consciousness. In The Essential Ken Wilber: An Introductory Reader. London: Shambala.

Wilber, K. (2001). A Theory of Everything-An Integral Vision for Business, Politics, Science, and Spirituality. Boston: Shambhala Publications.

Wilber, K. (2002). Integral Psychology: Consciousness, Spirit, Psychology, Therapy. Boston: Shambhala Publications.

Zappia, S. (2018). Weaknesses of Carl Jung's Theory.

https://classroom.synonym.com/weaknesses-carl-jungs-theory-8505105.html 